\title{
EFFECT OF SOME VITAMINS ON THE IONIC BALANCE AND PROTEIN PROFILES OF SALT- STRESSED FLAX SEEDLINGS
}

\author{
Manal M. Emam and Nesma M. Helal \\ Botany Department, Faculty of Science, Ain Shams Univeristy, Cairo, Egypt.
}

\begin{abstract}
The adverse effects of salinity on some physiological and biochemical responses of flax (Linum usitatissimum) seedlings grown at 100, 200, and $300 \mathrm{mM} \mathrm{NaCl}$ were studied. Salinity induced marked decreases percentage of germination, reduction in nucleic acids, as well as membrane stability index (MSI) of salinized flax seedlings. Data also revealed that salinized flax seedlings accumulated high levels of $\mathrm{Na}, \mathrm{Cl}, \mathrm{P}$ and $\mathrm{Mg}$ while $\mathrm{K}$ and $\mathrm{Ca}$ ions were significantly decreased. Application of some vitamins (folic acid, ascorbic acid and cobalamin) counteracted the adverse effects of salinity. The mechanism of these vitamins on alleviating salt stress hazards might be mediated by stimulating the de novo synthesis of new set of low molecular weight proteins, reduction in some ions $(\mathrm{Na}$ and $\mathrm{Cl})$ coupled with increases in the accumulation of others $(\mathrm{K}, \mathrm{Ca}, \mathrm{P}$ and $\mathrm{Mg}$ ), consequently vitamins maintain high percentage of MSI throughout the experiment, thereby enhanced the capacity for germination under salt stress conditions.
\end{abstract}

$\underline{\text { Key words: flax; salinity; vitamins; protein profile; membrane stability index. }}$

\section{INTRODUCTION}

Salt stress, like other abiotic stresses, can lead to oxidative stress through the increase in ROS which can damage essential membrane lipid as well as protein and nucleic acids (Noctor and Foyer, 1998). Maintenance of cellular ion homeostasis is fundamental to physiological activities in plants. The germination of the seed is an appropriate stage in the life of plants at which seeds are particularly sensitive to saline environment; in fact it has been found that the sensitivity to salt may be greater during germination than during seedling growth (Howell, 1998). A decline in seed germination percentage with increasing salinity was also reported in Atriplex spp (Ungar, 1996) and in Beta vulgaris (Ghoulam and Fares, 2001). Moreover, salinity stress slows down the rate of germination or inhibits it completely as recorded by (Radi et al., 1988; Nuran and Hüsnü, 2002).

The deleterious effect of salinity was suggested as a result of water stress, ion toxicity, ion imbalance, or combination of these factors. Mineral contents of many plants were found to be altered under salinity stress conditions particularly during seed germination (Izzo et al., 1991; Lutts et al., 1996). Indeed, salinity causes nutrient imbalances, consequently maintaining a suitable $\mathrm{K} / \mathrm{Na}$ ratio (Lacerda $\boldsymbol{e t}$ al., 2003) results in protection against the formation of ROS.

Relative accumulation of sodium in plant cell may induce some adaptation to high osmotic potential but excess sodium may be toxic as indicated by Lechno et al. (1996); Cicek and Cakirlar, (2002); Faheed et al. (2004) and Yildirim et al.( 2006).

ROS may also damage macromolecules such as DNA and proteins (Pastori and Foyer, 2002). Regulation of cellular ion homeostasis under salt stress is controlled by 
various kinds of membrane protein, such as channels or pumps (Serrano and RodrigguezNavarro, 2001). Several investigations have shown the synthesis of new proteins in many species when subjected to salinity stress (Hurkman and Tanaka, 1987; Singh et al., 1987). The synthesis of several proteins located in either membrane fraction (Hurkman et al., 1989), cytosol (Zhao and Herrmann, 1992; Reviron et al., 1992), chloroplasts (Winicov and Button, 1991) or intercellular spaces (Esaka et al., 1992) was found to be either up- or down- regulated by osmotic stress. These specifically synthesized proteins under salt stress appear to have a role in providing tolerance or adaptation to the plants. However, the overall mechanism of how these proteins could provide adaptation is not yet clear. Ericson and Alfinito (1984) reported the accumulation of 26 and 32-kDa proteins in salinized tobacco cells. The $26-\mathrm{kDa}$ protein (osmotin) is specifically synthesized and accumulated in cells undergoing osmotic adjustment to salt or desiccation stress, It is believed that osmotin provids osmotic adjustment to the cells either by inducing the accumulation of solutes or by providing certain metabolic alterations in the cell, which may be helpful in osmotic adjustment (Singh et al., 1987).

Hong-Bo et al. (2005) reported that, some salt induced proteins called late embryogenesis abundant (LEA) proteins (M.wt: 10-30 kDa) which may act as osmoprotectants and / or antioxidants against severe salt stress.

Amelioration of the adverse effects of $\mathrm{NaCl}$ salinity by addition of some vitamins have been reported by Li and Wang (1991) on Zea mays; Shalata and Neumann (2001) on Lycopersicum esculentum; Khattab (2001) on Oryza sativa; Ali (2002) on Ricinus communis; El-Bassiouny et al. (2005) on Vicia faba; Hamad and Hamada (2005) on Triticum aestivum; El-Tohamy and El-Gready (2007) on snap bean plants and Azooz (2009) on Hibiscus sabdariffa.

The role of ascorbic acid in alleviating hazards caused by salinity has been reported by many investigators (Mozafar and Oertli, 1992; Zhang and Kirkham, 1996; Khattab, 2001; Hamada and Hamada, 2005; Bassuony et al., 2008). However, the effect of exogenous application of folic acid and cobalamin as active oxygen scavengers have not been investigated to present date.

The objective of this study is to asses the possible roles of vitamins in the defense against ROS under salt stress conditions. Moreover, vitamins play an essential role in ion homeostasis and osmoregulation under salt stress; this may provide further information on repairing the injurious effects of salinity by vitamin applications.

\section{MATERIALS AND METHODS}

Pure strain of flax seeds (Linum usitatissimum L) cultivar, Sakha 2 was obtained from the Agriculture Research Center, Fiber Crops Research Section, Giza, Egypt. Preliminary experiments were done to test the salt sensitivity of flax seeds as well as to choose the proper concentrations of folic acid, ascorbic acid and cobalamin. Three different concentrations of sodium chloride were chosen $(100,200$, and $300 \mathrm{mM} \mathrm{NaCl}$ in $1 / 4$ strength Hogland's solution). The proper concentrations of folic acid (vitamin B9), ascorbic acid (vitamin C) and cobalamin (vitamin B12) were $20 \mu \mathrm{M}, 0.5 \mathrm{mM}$, and $2 \mu \mathrm{M}$ respectively. The seeds were surface sterilized by dipping in 1\% sodium hypochlorite solution for 5 minutes, then rinsed thoroughly with distilled water and germinated in Petri dishes on filter paper (Whatman No.1) saturated with $10 \mathrm{ml}$ water, vitamins and / or $\mathrm{NaCl}$ solutions. The solutions were replaced every 2-3 days. 
Seedlings were exposed to normal day length and natural temperature (about 22/13 $\pm 2^{\circ} \mathrm{C}$ and $11 \mathrm{~h}$ photoperiod). The number of germinated seeds was recorded daily through the experimental period. Seedlings were collected after 12 days at the end of the experiment for measuring some growth parameters in terms of fresh and dry weights of flax seedlings, mineral ion contents ( $\mathrm{Na}, \mathrm{K}, \mathrm{Ca}, \mathrm{Cl}, \mathrm{Mg}$ and $\mathrm{P}$ ), DNA and RNA, protein profile, as well as membrane stability index (MSI).

\section{Protein electrophoresis}

The total soluble proteins were separated on SDS-polyacrylamide gel and visualized by Coomassie blue stain to estimate the changes in protein profiles induced by $\mathrm{NaCl}$ stress in the absence and presence of vitamins. Electrophoretic determination of total protein was estimated according to their molecular weights by denatured sodium dodcyl sulphate polyacrylamide gel electrophoresis (SDS-PAGE) according to the method described by Laemmli (1970) and modified by Studier (1973).

Determination of membrane stability index (MSI).

MSI was measured as described by Sairam et al. (1997).

\section{Quantitative estimation of nucleic acids}

The method suggested by Ogur and Rosen (1950) for the extraction of nucleic acids was adopted in the present investigation.

\section{Determination of certain elements}

The method of extraction used in this investigation was essentially that of Chapman and Pratt (1961), sodium, potassium, and calcium were estimated according to the method described by Ranganna (1977) using atomic absorption spectrophotometer (Pekrin Elmer USA 3100). Phosphorous was estimated according to the method described by Humphries (1956). Magnesium can be calculated by multiplying the values of phosphorus by the factor: 0.0784 according to the method described by Word and Johnston (1962). Chloride ion concentration was measured by silver nitrate titration method as described by Jackson and Thomas (1960).

\section{Statistical Analysis}

Analysis of variance was conducted using ANOVA one way variance test using Microsoft Excel 2000. Statistical probability values were calculated to quantify the levels of significance for each treatment. The values of analysis of seedlings grown under 100, 200 and $300 \mathrm{mM} \mathrm{NaCl}$ were used as a reference controls for vitamin treated stressed ones, as well as they compared also, with the untreated control. Each treatment is an average of three different measurements.

\section{RESULTS}

\section{Changes in percentage of germination}

It is clearly shown that $\mathrm{NaCl}$ brought about a marked depressive effect on seed germination. Salinity stress delayed seed germination and reduced germination percentage particularly at high salinity levels $(200 \mathrm{mM} \mathrm{NaCl})$ as compared with non salinized control. Lower concentration of $\mathrm{NaCl}(100 \mathrm{mM})$ reduced the percentage of germination to $47 \%$. This reduction was positively related to $\mathrm{NaCl}$ concentrations (fig.1). The germination was 
completely inhibited in response to the higher concentration of $\mathrm{NaCl}(300 \mathrm{mM})$; non of these seeds could germinate during the incubation period. Flax seeds that fail to germinate at 300 $\mathrm{mM} \mathrm{NaCl}$, responded markedly to folic acid, ascorbic acid or cobalamin treatment which caused $67 \%, 34 \%$ and $33 \%$ respectively increase in germination percentage as compared with their corresponding control grown under sever salt stress $(300 \mathrm{mM} \mathrm{NaCl})$. Salinized seeds treated with any of the vitamins used in the present work germinated by the end of incubation period (Plates 1\&2).

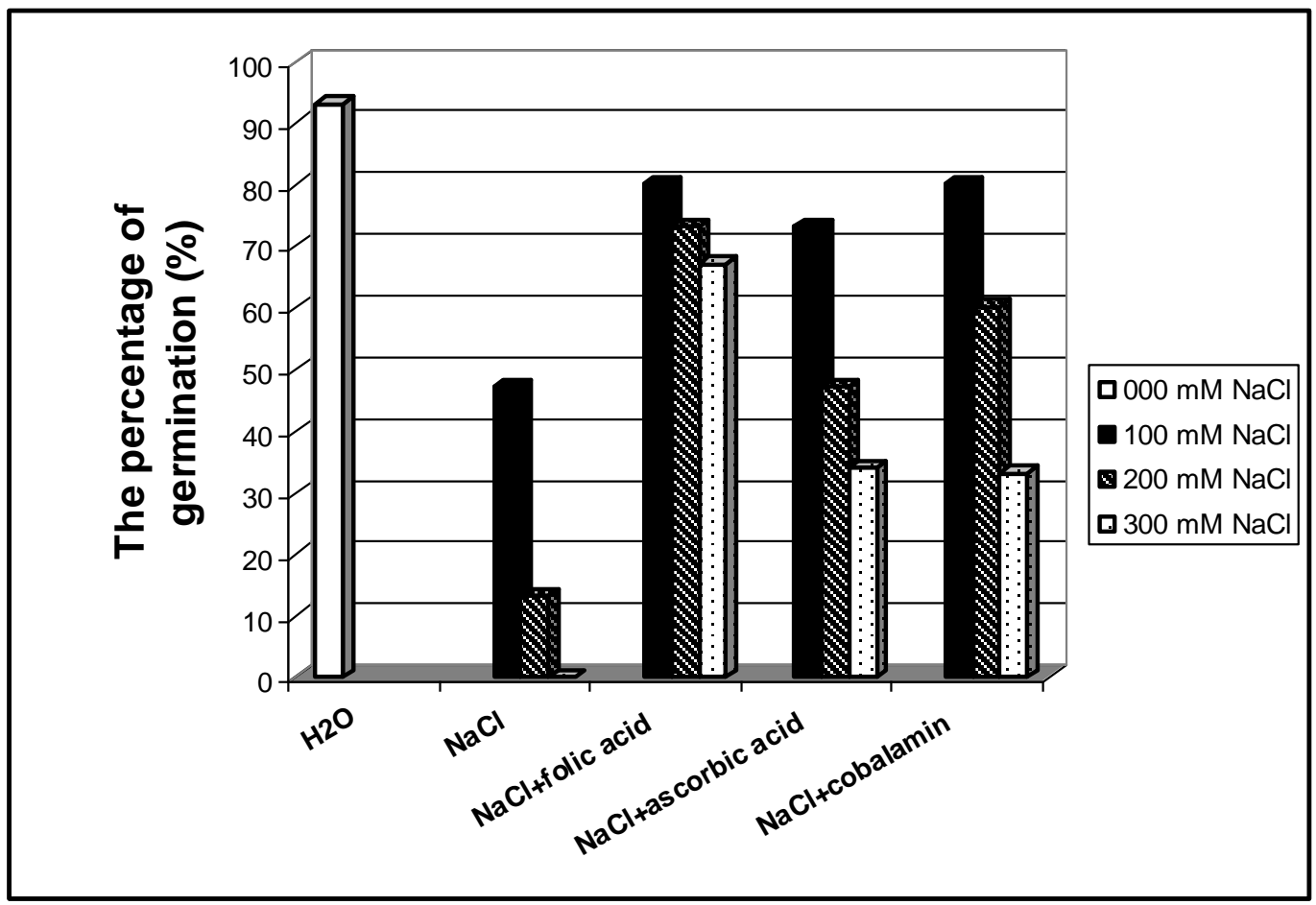

Figure (1): Effects of folic acid, ascorbic acid or cobalamin on the percentage of germination of Linum usitatissimum seeds grown under salt stress conditions.
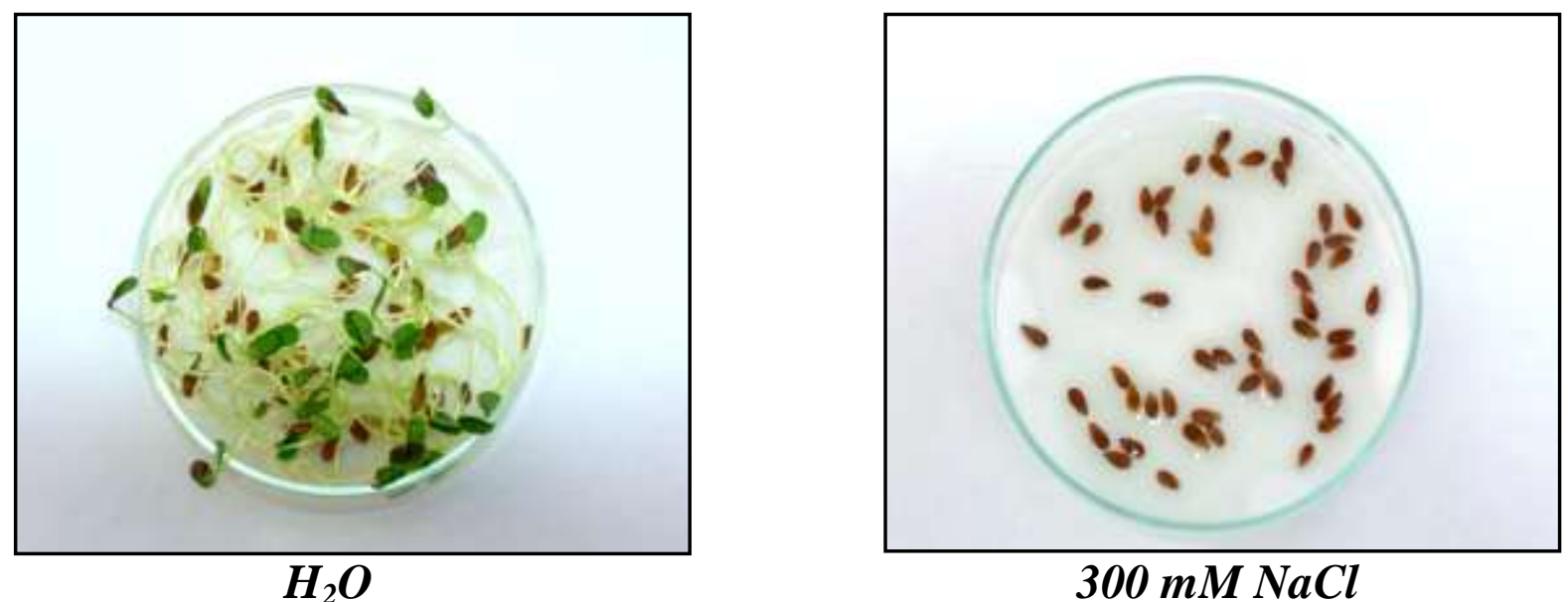

$300 \mathrm{mM} \mathrm{NaCl}$

Plate (1): Germination and growth responses pattern of Linum usitatissimum seeds grown under sever concentration of $\mathrm{NaCl}(300 \mathrm{mM})$. 


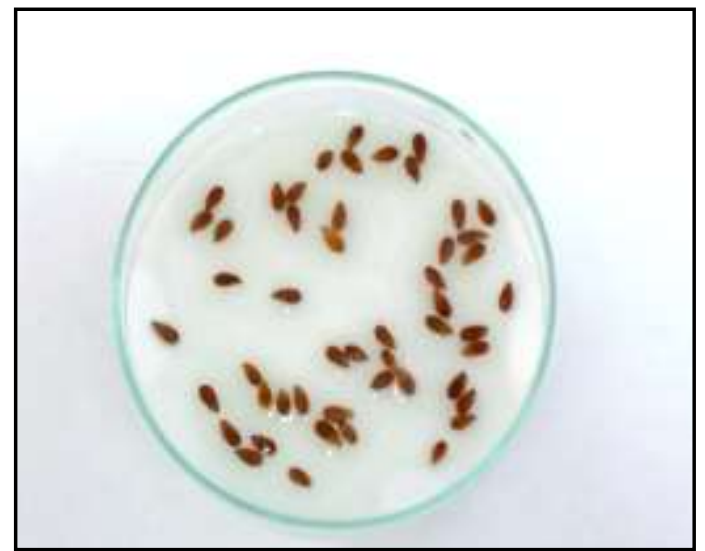

$300 \mathrm{mM} \mathrm{NaCl}$

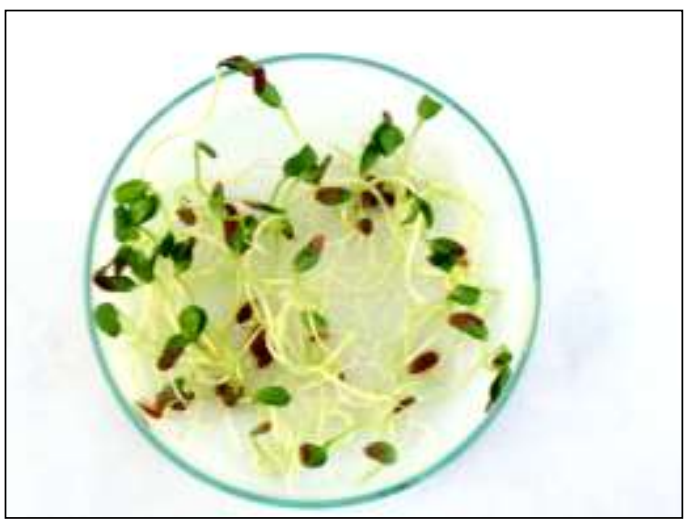

$300 \mathrm{mM} \mathrm{NaCl}+$ ascorbic acid

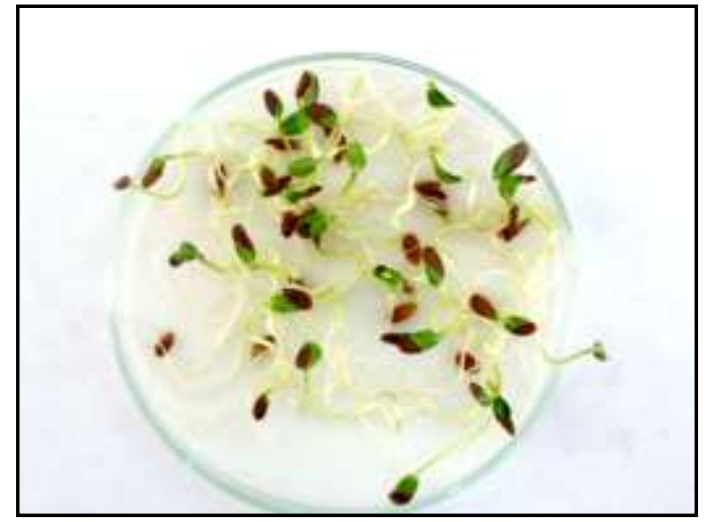

$300 \mathrm{mM} \mathrm{NaCl}+$ folic acid

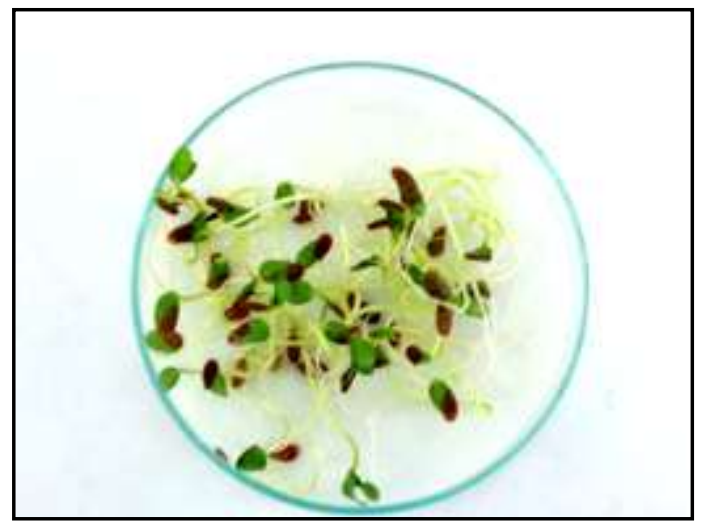

$300 \mathrm{mM} \mathrm{NaCl}+$ cobalamin

Plate (2): Germination and growth responses pattern of Linum usitatissimum seeds grown under sever salt stress conditions $(300 \mathrm{mM} \mathrm{NaCl})$ in the absence and presence of folic acid, ascorbic acid or cobalamin.

\section{Changes in biomass and membrane stability index (MSI)}

Data in table (1) revealed that salt stress induced significant reduction in both fresh and dry masses of salinized flax seedlings particularly at the high salinity levels. At $200 \mathrm{mM}$ $\mathrm{NaCl}$ the reduction in fresh and dry matter yields of salinized flax seedlings was $68.7 \%$ and $45.3 \%$ respectively below the control value. 
Table 1 Effects of folic acid, ascorbic acid or cobalamin on some growth parameters of Linum usitatissimum seedlings grown under salt stress conditions. Each value is a mean of ten replicates $\pm \mathrm{SE}$

\begin{tabular}{|c|c|c|c|c|}
\hline Treatments & $\begin{array}{l}\mathrm{NaCl} \\
(\mathrm{mM})\end{array}$ & $\begin{array}{l}\text { Fresh weight } \\
\text { (g/seedling) }\end{array}$ & $\begin{array}{l}\text { Dry weight } \\
\text { (g/seedling) }\end{array}$ & $\begin{array}{c}(\text { MSI }) \\
\text { Membrane stability } \\
\text { index }(\%)\end{array}$ \\
\hline $\mathrm{NaCl}$ & $\begin{array}{l}000 \\
100 \\
200 \\
300 \\
\end{array}$ & $\begin{array}{c}1.387 \pm 0.6 \\
0.649 \pm 0.2^{\mathrm{c}} \\
0.434 \pm 0.1^{\mathrm{c}} \\
0.299 \pm 0.1^{\mathrm{c}}\end{array}$ & $\begin{array}{c}0.075 \pm 0.02 \\
0.064 \pm 0.01 \\
0.041 \pm 0.01^{\mathrm{a}} \\
0.010 \pm 0.01^{\mathrm{c}} \\
\end{array}$ & $\begin{array}{c}79.5 \pm 2.4 \\
25.0 \pm 1.3^{\mathrm{c}} \\
21.4 \pm 1.1^{\mathrm{c}} \\
05.1 \pm 0.4^{\mathrm{c}}\end{array}$ \\
\hline $\mathrm{NaCl}+$ folic acid & $\begin{array}{l}100 \\
200 \\
300\end{array}$ & $\begin{array}{c}0.780 \pm 0.3 \\
0.847 \pm 0.2^{\mathrm{a}} \\
0.380 \pm 0.1\end{array}$ & $\begin{array}{l}0.080 \pm 0.03 \\
0.130 \pm 0.04^{\mathrm{b}} \\
0.068 \pm 0.01^{\mathrm{a}}\end{array}$ & $\begin{array}{l}66.6 \pm 3.5^{\mathrm{b}} \\
50.0 \pm 2.1^{\mathrm{c}} \\
18.0 \pm 0.9^{\mathrm{c}}\end{array}$ \\
\hline $\begin{array}{c}\mathrm{NaCl}+\text { ascorbic } \\
\text { acid }\end{array}$ & $\begin{array}{l}100 \\
200 \\
300\end{array}$ & $\begin{array}{c}0.815 \pm 0.3 \\
0.896 \pm 0.4^{b} \\
0.332 \pm 0.1\end{array}$ & $\begin{array}{l}0.115 \pm 0.03^{\mathrm{a}} \\
0.103 \pm 0.02^{\mathrm{b}} \\
0.061 \pm 0.01^{\mathrm{a}}\end{array}$ & $\begin{array}{l}52.6 \pm 2.7^{\mathrm{b}} \\
33.3 \pm 1.8^{\mathrm{b}} \\
15.0 \pm 0.7^{\mathrm{c}}\end{array}$ \\
\hline $\mathrm{NaCl}+$ cobalamin & $\begin{array}{l}100 \\
200 \\
300\end{array}$ & $\begin{array}{c}0.856 \pm 0.2 \\
0.786 \pm 0.3^{\mathrm{a}} \\
0.341 \pm 0.1\end{array}$ & $\begin{array}{l}0.136 \pm 0.04^{b} \\
0.121 \pm 0.03^{b} \\
0.062 \pm 0.01^{a}\end{array}$ & $\begin{array}{l}50.0 \pm 2.2^{\mathrm{c}} \\
40.2 \pm 1.9^{\mathrm{b}} \\
11.1 \pm 0.7^{\mathrm{c}}\end{array}$ \\
\hline
\end{tabular}

Values with a superscript are significant different from the control. Letter $\mathrm{a}={ }^{*}$ at $\mathrm{P}>0.05, \mathrm{~b}$ $=* *$ at $\mathrm{P}<0.01, \mathrm{c}=* * *$ at $\mathrm{P}<0.001$, and absence of letter $=$ non significant.

Vitamin treatments greatly reduce the inhibitory effects of salinity on growth of flax seedlings. This stimulatory effect was more pronounced in cobalamin-treated flax seeds, such effect reaches about $31.8 \%$ and $112.5 \%$ increase in fresh and dry weights at $100 \mathrm{mM}$ $\mathrm{NCl}$ compared to the reference control.

Membrane stability index (MSI) was estimated as electrolyte leakage. The results revealed that, membrane stability index significantly decreased in salinized flax seedlings. Lower dose of $\mathrm{NaCl}(100 \mathrm{mM})$ reduced the percentage of MSI by $68.5 \%$ below the control value. This reduction was positively related to the concentrations $\mathrm{NaCl}$. Vitamin treatments significantly increased the MSI percentage particularly in folic acid treated salinized seedlings.

\section{Changes in Protein banding Pattern}

Scanning of the gel revealed the appearance of a number of polypeptide bands ranging from 4-14 polypeptide bands (Plate $3 \&$ Table 2). 


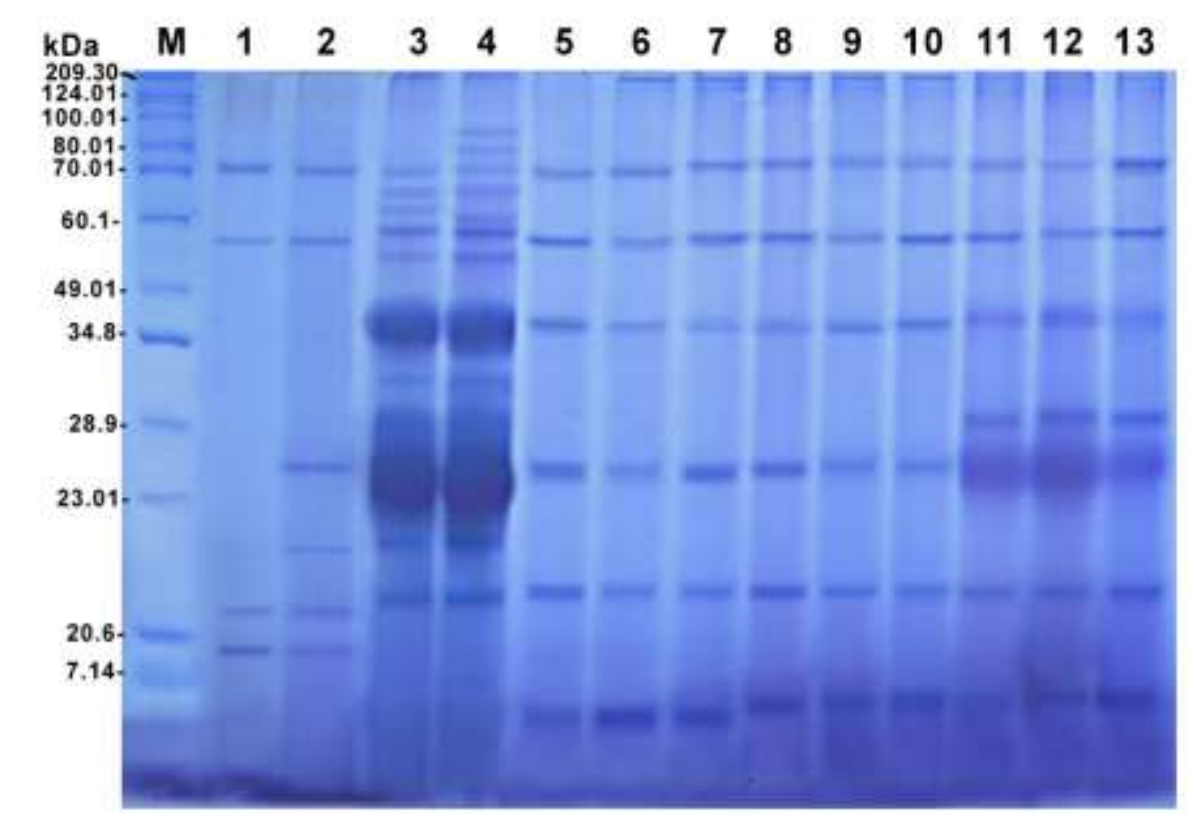

Plate (3): Electrograph SDS-PAGE of total soluble protein extracted from Linum usitatissimum seedlings grown under different concentrations of $\mathrm{NaCl}$ in the absence and presence of folic acid, ascorbic acid or cobalamin.

$\mathrm{M}:$ Marker

Lane $1: 000 \mathrm{mM} \mathrm{NaCl}$

Lane $2: 100 \mathrm{mM} \mathrm{NaCl}$

Lane $3: 200 \mathrm{mM} \mathrm{NaCl}$

Lane $4: 300 \mathrm{mM} \mathrm{NaCl}$

Lane $5: 100 \mathrm{mM} \mathrm{NaCl}+$ ascorbic acid

Lane $6: 100 \mathrm{mM} \mathrm{NaCl}+$ cobalamin

Lane $7: 100 \mathrm{mM} \mathrm{NaCl}+$ folic acid

Lane $8: 200 \mathrm{mM} \mathrm{NaCl}+$ ascorbic acid

Lane $9: 200 \mathrm{mM} \mathrm{NaCl}+$ cobalamin

Lane $10: 200 \mathrm{mM} \mathrm{NaCl}+$ folic acid

Lane $11: 300 \mathrm{mM} \mathrm{NaCl}+$ ascorbic acid

Lane $12: 300 \mathrm{mM} \mathrm{NaCl}+$ cobalamin

Lane $13: 300 \mathrm{mM} \mathrm{NaCl}+$ folic acid

Table (2): Relative concentration (band \%), molecular weight (M.wt) and mobility rate (Rm) of the SDS-PAGE of total soluble protein extracted from Linum usitatissimum seedlings treated with folic acid, ascorbic acid or cobalamin and exposed to different concentrations of $\mathrm{NaCl}$.

\begin{tabular}{|c|c|c|c|c|c|c|c|c|c|c|c|c|c|c|c|}
\hline \multirow[t]{2}{*}{ Band No } & \multicolumn{13}{|c|}{ Treatment and Band \% } & \multirow[t]{2}{*}{$\mathbf{R m}$} & \multirow{2}{*}{$\begin{array}{c}\text { M.wt. } \\
\text { kDa }\end{array}$} \\
\hline & 1 & 2 & 3 & 4 & 5 & 6 & 7 & 8 & 9 & 10 & 11 & 12 & 13 & & \\
\hline 1 & - & - & 4.40 & 3.01 & - & 20.07 & 11.70 & 10.08 & 20.03 & 20.03 & 3.02 & 4.80 & 6.72 & 0.02 & 209.3 \\
\hline 2 & - & - & - & 3.38 & - & - & - & - & - & - & - & - & - & 0.07 & 97.7 \\
\hline 3 & - & - & - & 3.07 & - & - & - & - & - & - & - & - & - & 0.09 & 80.4 \\
\hline 4 & 30.24 & 20.35 & 3.33 & 3.16 & 20.31 & 18.62 & 10.39 & 13.72 & 13.11 & 15.07 & 8.02 & 3.84 & 5.82 & 0.12 & 75.9 \\
\hline 5 & - & - & 3.18 & 3.07 & - & - & - & - & - & - & - & - & - & 0.15 & 68.3 \\
\hline 6 & - & - & 2.91 & 2.82 & - & - & - & - & - & - & - & - & - & 0.18 & 65.4 \\
\hline 7 & 19.34 & 39.05 & 22.92 & 8.52 & 10.19 & 19.68 & 12.93 & 9.72 & 14.68 & 20.49 & 7.07 & 4.50 & 5.41 & 0.23 & 58.2 \\
\hline 8 & - & - & 5.47 & 3.09 & - & - & - & - & - & - & - & - & - & 0.24 & 55.4 \\
\hline 9 & - & - & 2.90 & 3.10 & 10.04 & 8.12 & 8.34 & 10.06 & 16.14 & 10.09 & 13.00 & 8.18 & 9.36 & 0.27 & 45.0 \\
\hline 10 & - & - & 34.54 & 31.59 & - & - & - & - & - & - & - & - & - & 0.32 & 32.0 \\
\hline 11 & - & - & 3.54 & 3.38 & - & - & - & - & - & - & 10.15 & 9.39 & 7.29 & 0.39 & 28.5 \\
\hline 12 & - & 13.03 & 3.40 & 12.59 & 2.24 & 6.95 & 16.50 & 8.07 & 7.54 & 8.04 & 36.39 & 34.72 & 38.97 & 0.40 & 26.3 \\
\hline 13 & - & 9.30 & 6.00 & 9.00 & - & - & - & - & - & - & - & - & - & 0.49 & 23.7 \\
\hline 14 & 19.69 & 10.96 & 7.41 & 10.04 & 39.17 & 12.70 & 26.14 & 35.55 & 20.21 & 14.14 & 13.27 & 26.52 & 14.82 & 0.54 & 20.9 \\
\hline 15 & 30.73 & 7.00 & - & - & - & - & - & - & - & - & - & - & - & 0.69 & 15.0 \\
\hline 16 & - & - & - & - & 18.05 & 13.86 & 14.00 & 12.80 & 8.23 & 12.12 & 9.08 & 8.00 & 11.61 & 0.74 & 6.2 \\
\hline $\begin{array}{c}\text { No. of } \\
\text { Bands/lane }\end{array}$ & 4 & 6 & 12 & 14 & 6 & 7 & 7 & 7 & 7 & 7 & 8 & 8 & 8 & & \\
\hline
\end{tabular}


Three common protein bands with M.wt: 75.9, 58.2 and $20.9 \mathrm{kDa}$ were detected in the control and in response to the treatments with the three applied concentrations of $\mathrm{NaCl}$ in the absence and presence of vitamins.

It is clearly shown from table (2) that, the low salinity level resulted in the appearance of two new protein bands (M.wt: 26.3 and $23.7 \mathrm{kDa}$ ), the moderate salt concentration $(200 \mathrm{mM} \mathrm{NaCl})$ resulted in the appearance of 9 polypeptides bands (M.wt: 209.3, 68.3, 65.4, 55.4, 45.0, 32.0, 28.5, 26.3 and 23.7 kDa), six of which disappeared in response to vitamin treatments (M.wt: 68.3, 65.4, 55.4, 32.0, 28.5 and $23.7 \mathrm{kDa}$ ). At high salinity level (300 mM NaCl), 11 polypeptide bands were detected (M.wt: 209.3, 97.7, 80.4, $68.3,65.4,55.4,45.0,32.0,28.5,26.3$ and $23.7 \mathrm{kDa}$ ), seven of which disappeared in response to vitamin treatments (M. wt: 97.7, 80.4, 68.3, 65.4, 55.4, 32.0 and $23.7 \mathrm{kDa}$ ).

Moreover the electrophoretic pattern confirms the specific accumulation of low molecular weight protein (M.wt: $6.2 \mathrm{kDa}$ ) in salinized flax seedlings treated with folic acid, ascorbic acid or cobalamin.

\section{Changes in mineral composition}

The results revealed that salinity is capable of inducing a general increase in $\mathrm{Na}, \mathrm{Cl}$, $\mathrm{P}$ and $\mathrm{Mg}$ ions while $\mathrm{K}$ and $\mathrm{Ca}$ ions were significantly decreased as salinity levels increased. Seed treatment with any of the applied vitamins was generally of depressive effect on the accumulation of $\mathrm{Na}$ as well as $\mathrm{Cl}$ ions. However, they have stimulatory effects on the accumulation of $\mathrm{K}, \mathrm{Ca}, \mathrm{Mg}$ and $\mathrm{P}$ ions as well as $\mathrm{K} / \mathrm{Na}, \mathrm{Ca} / \mathrm{Na}, \mathrm{Mg} / \mathrm{Na}$ and $\mathrm{P} / \mathrm{Na}$ ratios.

The of reduction in $\mathrm{Na}$ ions level due to folic acid treatment in salinized flax seedlings was from $44.0 \%$ to $65.1 \%$, while in case of ascorbic acid treatment it was from $41.3 \%$ to $50.4 \%$ below their corresponding controls. With respect to cobalamin treatment, the decrease in $\mathrm{Na}$ ions level below the control values was $61.7 \%, 56.7 \%$ and $51.6 \%$ at different concentrations of $\mathrm{NaCl}$ (Table 3).

Table 3 Effects of folic acid, ascorbic acid or cobalamin on mineral composition of Linum usitatissimum seedlings grown under salt stress conditions. Values are listed are expressed as $\mathrm{mg} / \mathrm{g}$ dry weight. Each value is a mean of three replicates $\pm \mathrm{SD}$

\begin{tabular}{|c|c|c|c|c|c|c|c|}
\hline Treatments & $\begin{array}{l}\mathrm{NaCl} \\
(\mathrm{mM})\end{array}$ & $N a$ & $K$ & $\mathrm{Ca}$ & $M g$ & $P$ & $\mathrm{Cl}$ \\
\hline $\mathrm{NaCl}$ & $\begin{array}{l}000 \\
100 \\
200 \\
300\end{array}$ & $\begin{array}{c}16.1 \pm 0.9^{\mathrm{c}} \\
58.2 \pm 2.8^{\mathrm{c}} \\
81.3 \pm 7.5^{\mathrm{c}} \\
106.2 \pm 9.8^{\mathrm{c}}\end{array}$ & $\begin{array}{c}72.7 \pm 6.9 \\
70.2 \pm 6.5 \\
60.2 \pm 4.3^{\mathrm{a}} \\
38.7 \pm 2.1^{\mathrm{c}}\end{array}$ & $\begin{array}{c}62.3 \pm 5.7 \\
51.8 \pm 3.7 \\
49.2 \pm 3.1^{\mathrm{b}} \\
46.1 \pm 3.1^{\mathrm{b}}\end{array}$ & $\begin{array}{l}0.68 \pm 0.1 \\
1.27 \pm 0.2^{\mathrm{a}} \\
1.38 \pm 0.4^{\mathrm{b}} \\
1.52 \pm 0.5^{\mathrm{c}}\end{array}$ & $\begin{array}{c}8.7 \pm 1.0 \\
16.2 \pm 1.1^{\mathrm{a}} \\
17.6 \pm 1.3^{\mathrm{b}} \\
19.3 \pm 1.5^{\mathrm{c}}\end{array}$ & $\begin{array}{c}6.3 \pm 0.4 \\
37.9 \pm 2.9^{\mathrm{c}} \\
48.5 \pm 4.6^{\mathrm{c}} \\
64.5 \pm 7.6^{\mathrm{c}}\end{array}$ \\
\hline $\begin{array}{c}\mathrm{NaCl}+\text { folic } \\
\text { acid }\end{array}$ & $\begin{array}{l}100 \\
200 \\
300\end{array}$ & $\begin{array}{l}20.3 \pm 1.2^{\mathrm{b}} \\
45.5 \pm 2.1^{\mathrm{b}} \\
52.1 \pm 2.4^{\mathrm{c}}\end{array}$ & $\begin{array}{l}128.1 \pm 9.9^{b} \\
99.9 \pm 8.8^{b} \\
99.1 \pm 9.8^{c}\end{array}$ & $\begin{array}{l}59.1 \pm 4.2 \\
81.5 \pm 7.8^{\mathrm{b}} \\
62.1 \pm 4.9^{\mathrm{b}}\end{array}$ & $\begin{array}{l}1.67 \pm 0.4 \\
1.61 \pm 0.5 \\
1.54 \pm 0.4\end{array}$ & $\begin{array}{l}21.3 \pm 2.1 \\
20.5 \pm 1.8 \\
19.6 \pm 1.6\end{array}$ & $\begin{array}{l}30.8 \pm 2.4^{\mathrm{a}} \\
43.0 \pm 4.2 \\
44.8 \pm 4.3^{\mathrm{b}}\end{array}$ \\
\hline $\begin{array}{c}\mathrm{NaCl}+\text { ascorbic } \\
\text { acid }\end{array}$ & $\begin{array}{l}100 \\
200 \\
300\end{array}$ & $\begin{array}{l}31.5 \pm 1.7^{\mathrm{b}} \\
40.3 \pm 2.4^{\mathrm{c}} \\
62.3 \pm 4.6^{\mathrm{c}}\end{array}$ & $\begin{array}{c}171.1 \pm 12.0^{\mathrm{c}} \\
139.2 \pm 10.2^{\mathrm{c}} \\
85.0 \pm 7.8^{\mathrm{c}}\end{array}$ & $\begin{array}{l}50.1 \pm 5.2 \\
54.2 \pm 4.9 \\
53.4 \pm 6.0\end{array}$ & $\begin{array}{l}2.26 \pm 0.9^{\mathrm{a}} \\
1.59 \pm 0.4 \\
1.47 \pm 0.3\end{array}$ & $\begin{array}{l}28.8 \pm 1.9^{\mathrm{a}} \\
20.3 \pm 1.7 \\
18.8 \pm 1.8\end{array}$ & $\begin{array}{c}9.0 \pm 1.2^{\mathrm{c}} \\
9.5 \pm 1.3^{\mathrm{c}} \\
18.6 \pm 2.0^{\mathrm{c}}\end{array}$ \\
\hline $\mathrm{NaCl}+$ cobalamin & $\begin{array}{l}100 \\
200 \\
300\end{array}$ & $\begin{array}{l}22.3 \pm 1.4^{\mathrm{b}} \\
35.2 \pm 1.4^{\mathrm{c}} \\
51.4 \pm 3.6^{\mathrm{c}}\end{array}$ & $\begin{array}{l}87.2 \pm 9.4^{\mathrm{a}} \\
90.5 \pm 8.5^{\mathrm{b}} \\
96.0 \pm 9.3^{\mathrm{c}}\end{array}$ & $\begin{array}{l}49.3 \pm 3.2 \\
82.3 \pm 6.9^{\mathrm{c}} \\
61.2 \pm 5.4^{\mathrm{b}}\end{array}$ & $\begin{array}{l}1.73 \pm 0.4^{\mathrm{a}} \\
1.59 \pm 0.3 \\
1.58 \pm 0.2\end{array}$ & $\begin{array}{l}22.1 \pm 1.3^{\mathrm{a}} \\
20.4 \pm 1.5 \\
20.1 \pm 1.2\end{array}$ & $\begin{array}{l}9.5 \pm 1.1^{\mathrm{c}} \\
16.6 \pm 1.4^{\mathrm{c}} \\
43.2 \pm 3.6^{\mathrm{b}}\end{array}$ \\
\hline
\end{tabular}


Values with a superscript are significant different from the control. Letter $\mathrm{a}=*$ at $\mathrm{P}>0.05, \mathrm{~b}=* *$ at $\mathrm{P}<0.01, \mathrm{c}=* * *$ at $\mathrm{P}<0.001$, and absence of letter $=$ non significant.

In addition, the reduction in the $\mathrm{Cl}$ ion concentrations due to vitamin treatments was more pronounced in ascorbic acid treatment where it reached about $71.2 \%$ below its corresponding control $(300 \mathrm{mM} \mathrm{NaCl})$.

It is worthy to note that, the maximum increase of $\mathrm{K}$ ion levels measured in salinized flax seedlings treated with ascorbic acid was $131.2 \%$ compared to its corresponding control $(200 \mathrm{mM} \mathrm{NaCl})$. However, at the same level the increase in $\mathrm{K}$ in response to folic acid or cobalamin treatment was $65.9 \%$ and $50.0 \%$ respectively compared with their corresponding control.

\section{Changes in nucleic acid contents}

Salinity induced a significant reduction in DNA and RNA contents of flax seedlings (Table 5). This reduction was salt concentration dependant. A non- significant reduction in RNA content was observed in flax seedlings exposed to $100 \mathrm{mM} \mathrm{NaCl}$, The decreases in RNA levels were about $6.4 \%, 19.0 \%$ and $25.3 \%$ at 100,200 and $300 \mathrm{mM} \mathrm{NaCl}$ respectively below the control value.

Similarly the decrease in DNA content was about $38.4 \%, 41.1 \%$ and $52.8 \%$ respectively at the same salinity levels. The application of folic acid, ascorbic acid or cobalamin alleviated the inhibitory effects of $\mathrm{NaCl}$ on RNA synthesis but significantly reduced DNA level as being compared with the corresponding control.

\section{DISCUSSION}

The present study suggests that, flax seeds tolerated $\mathrm{NaCl}$ salinity up to $200 \mathrm{mM}$ $\mathrm{NaCl}$; the germination was completely inhibited at $300 \mathrm{mM} \mathrm{NaCl}$. Salinity stress inhibits seed germination either due to accumulation of toxic ions (Ramagopal, 1988); or through osmotic stress which reduce the uptake of water (Sharma, 1990). This is the case in our study it was clearly shown that under salinity stress $\mathrm{Na}$ was sharply accumulated in salinized flax seedlings while $\mathrm{K}$ concentration as well as $\mathrm{K} / \mathrm{Na}, \mathrm{Ca} / \mathrm{Na}, \mathrm{Mg} / \mathrm{Na}$ and $\mathrm{P} / \mathrm{Na}$ ratios were significantly decreased as salinity levels increased (Tables 3 and 4). On the other hand, the completely non germinated flax seeds (at $300 \mathrm{mM} \mathrm{NaCl}$ ) showing an amazing capacity for recovery and germination when exposed to folic acid, ascorbic acid or cobalamin treatments (Plates1 \& 2). It is interesting to note here that vitamin treatments greatly nullify the inhibitory effects of salinity on growth of flax seedlings (Table 1). Salt stress leads to changes in growth, morphology and physiology of roots that would in turn change water and ion uptake (Alpaslan and Gunes, 2001; Alves da costa et al., 2005; Salter et al., 2007). Reduced rate of new cell production may make additional contributions to inhibition of growth (Boscaiu et al., 2005). In this respect ascorbic acid is implicated in regulation of root elongation and cell wall expansion of many plant species (Noctor and Foyer, 1998). Folic acid and cobalamin are known to be necessary for cell division (Andrew et al., 2000; Smith et al., 2007). 
Table 4 Effects of folic acid, ascorbic acid or cobalamin on $\mathrm{K} / \mathrm{Na}, \mathrm{Ca} / \mathrm{Na}, \mathrm{Mg} / \mathrm{Na}$ and $\mathrm{P} / \mathrm{Na}$ ratios of Linum usitatissimum seedlings grown under salt stress conditions. Values are listed are expressed as $\mathrm{mg} / \mathrm{g}$ dry weight.

\begin{tabular}{|c|c|c|c|c|c|}
\hline Treatments & $\begin{array}{r}\mathrm{NaCl} \\
(\mathrm{mM})\end{array}$ & $\mathrm{K} / \mathrm{Na}$ & $\mathrm{Ca} / \mathrm{Na}$ & $\mathrm{Mg} / \mathrm{Na}$ & $\mathrm{P} / \mathrm{Na}$ \\
\hline \multirow{4}{*}{$\mathrm{NaCl}$} & 000 & 4.52 & 3.87 & 0.04 & 0.54 \\
\hline & 100 & 1.21 & 0.89 & 0.02 & 0.27 \\
\hline & 200 & 0.74 & 0.61 & 0.01 & 0.21 \\
\hline & 300 & 0.36 & 0.43 & 0.01 & 0.18 \\
\hline \multirow{3}{*}{$\mathrm{NaCl}+$ folic acid } & 100 & 6.31 & 2.91 & 0.08 & 1.05 \\
\hline & 200 & 2.19 & 1.79 & 0.03 & 0.45 \\
\hline & 300 & 1.90 & 1.19 & 0.02 & 0.37 \\
\hline \multirow{3}{*}{$\begin{array}{c}\mathrm{NaCl}+\text { ascorbic } \\
\text { acid }\end{array}$} & 100 & 5.43 & 1.59 & 0.05 & 0.91 \\
\hline & 200 & 3.45 & 1.34 & 0.03 & 0.55 \\
\hline & 300 & 1.36 & 0.86 & 0.02 & 0.30 \\
\hline \multirow{3}{*}{$\mathrm{NaCl}+$ cobalamin } & 100 & 3.91 & 2.21 & 0.07 & 0.94 \\
\hline & 200 & 2.57 & 2.21 & 0.04 & 0.58 \\
\hline & 300 & 1.86 & 1.19 & 0.03 & 0.39 \\
\hline
\end{tabular}

Membrane stability index has been used to assess tolerance of various plant species (Sudhakar et al., 2001; Eraslan et al., 2007: Azooz, 2009).

The membrane injury in salinized flax seedlings was concomitant in most cases with sharp decrease in membrane stability index (MSI). MSI was subjected to a significant increase in salinized flax seedlings exposed to folic acid, ascorbic acid or cobalamin (Table 1). The maintenance of high percentage of MSI throughout the experiment show that vitamin-treated salinized flax seedlings can overcome hazards caused by salt stress.

One approach to understanding the ability of flax seedlings to tolerate salt stress has been to identify stress-induced changes of individual proteins under the assumption that stress adaptation results from alterations in gene expression (Natarajan et al. 1996).

The observed changes in protein profile and consequently the physiological responses suggested that the changes in protein pattern might play a critical role in the response of flax seedling to salt stress (Table 3). The present data revealed the presence of three common protein bands (M.wt: 75.9, 58.2 and $20.9 \mathrm{kDa}$ ) detected in the control and in response to the various concentrations of $\mathrm{NaCl}$ in the absence and presence of the vitamins which might be specific for flax seedlings irrespective of the treatments. In addition sever salt stress $(300 \mathrm{mM} \mathrm{NaCl})$ induced the de novo synthesis of salt specific polypeptides (M.wt: 209.3, 97.7, 80.4, 68.3, 65.4, 55.4, 45.0, 32.0, 28.5, 26.3 and 23.7 kDa). These salt specific proteins might be involved in salt tolerance and / or a member of LEA family which are acting as antioxidants; membrane and protein stabilizers (De Abreu and Mazzafera, 2005). It is suggested that not all proteins produced in saline condition are correlate with stress tolerance, which might be the case in our study. In spite of the detection of 26 and $32-\mathrm{kDa}$ proteins under salt stress $(200$ and $300 \mathrm{mM} \mathrm{NaCl})$, the membrane injury in salinized flax seedlings was concomitant with sharp decrease in membrane stability index (MSI). 
Consequently, these polypeptides may not have a function in the process of salt adaptation in flax seedlings grown under sever salt stress conditions.

The new protein bands which accumulated in response to salt stress and disappeared in the vitamin treated seedlings (M.wt: 97.7, 80.4, 68.3, 65.4, 55.4, 32.0 and $23.7 \mathrm{kDa}$ ) might be responsible for the observed decrease in MSI under sever salt stress. The disappearance of some high molecular weight proteins in response to all the previous treatments might be attributed to the increase of the synthesis of other proteins (Robinson et al., 1990). The greatest increase in the concentration (measured as band intensity) of the low molecular weight protein (M.wt: $6.2 \mathrm{kDa}$ ) in salinized flax seedlings treated with any of the vitamins was concomitant with the better performance of flax seedlings grown under saline conditions (Table 2). The most characteristic feature of vitamin treatments is their role on stimulating the biosynthesis of new set of low molecular weight proteins in addition to the disappearance of others. These proteins might be enzymes and / or phytohormone receptors (Napeir and Venis, 1990; Dunn, 1993).

The accumulation of ions in different plant species facilitate the osmotic adjustment and increase the tolerance of these plants to saline environment. In the present study, it was clearly shown that under salinity stress $\mathrm{Na}$ was sharply accumulated in salinized flax seedlings while $\mathrm{K}$ concentration as well as $\mathrm{K} / \mathrm{Na}, \mathrm{Ca} / \mathrm{Na}, \mathrm{Mg} / \mathrm{Na}$ and $\mathrm{P} / \mathrm{Na}$ ratios were significantly decreased as salinity levels increased (Tables 3 and 4). These results are in confirmatory with the results obtained by many authors who found that salt stress was found to alter the mineral content of many plants particularly during germination. Salinity stress frequently induces an increase in $\mathrm{Na}$ and $\mathrm{Cl}$ as well as a decrease in $\mathrm{K}$ and $\mathrm{Ca}$ concentrations (Izzo et al., 1991; Lutts et al., 1996; Alpasian and Gunes 2001; Inal, 2002). It was suggested that, the effect of salinity on mineral ions was due to decrease in leaf water potential, relative water content, and water retention capacity concurrently with increased water saturation deficit (Kabir et al., 2004). The observed increase in Na might be attributed to the fact that, under salinity stress the uptake of $\mathrm{Na}$ ions was increased, while the contrary was observed with respect to $\mathrm{K}$ ions. Also, the competition between potassium and sodium has been reported (Yildirim et al., 2006; Roussos et al., 2007; López et al., 2008). The antagonistic relation between $\mathrm{Na}$ and $\mathrm{K}$ ions indicated that, the high levels of $\mathrm{Na}$ ions generated a kind of competition on the level of sites of $\mathrm{K}$ ions absorption and thus limited the absorption of $\mathrm{K}$ (Rejili et al., 2007). The high content of $\mathrm{Na}$ could disrupt the nutrient balance, thereby causing specific ions toxicity despite disturbing osmotic regulation. While the reduction in $\mathrm{K}$ concentration could inhibit growth by reducing the capacity for osmotic adjustment and turgor maintenance or by adversely affecting metabolic functions (Ashraf and Harris, 2004; López et al., 2008; Inal et al., 2009).

There was a beneficial effect of vitamin treatments which was reflected in the reduction in $\mathrm{Na}$ and $\mathrm{Cl}$ and increases in $\mathrm{K}, \mathrm{Ca}, \mathrm{Mg}$, and $\mathrm{P}$ contents. Consequently $\mathrm{K} / \mathrm{Na}$, $\mathrm{Ca} / \mathrm{Na}, \mathrm{Mg} / \mathrm{Na}$ and $\mathrm{P} / \mathrm{Na}$ ratios (Tables 3 and 4). This may represent a tool exerted by the vitamin-treated plants to partially overcome the toxic effect of $\mathrm{NaCl}$ during salt stress.

There are many reports indicating the importance of adequate levels of $\mathrm{Ca}$ in alleviating the deleterious effects of salinity on plant growth (Sivritepe et al., 2003). Moreover, calcium ${ }^{\text {functions }}$ to limit intercellular $\mathrm{Na}$ ions accumulation by regulating processes that restrict influx and enhance efflux of these cations across the plasma membrane (Pardo et al., 1998). On the other hand, one of the mechanisms of damage by salt is through displacement of $\mathrm{Ca}$ ions from functional sites as reported by Jeschke et al. (1986).

Under salt stress, protecting the DNA was a priority which is confirmed by the data reported by Hasegawa and Bressan (2000) Hamed (2004). The results observed in the 
present work and those obtained by many other investigators show that, salinity disturbed nucleic acid metabolism (Table 5). Both DNA and RNA contents were markedly decreased with the increase in the applied $\mathrm{NaCl}$ doses. The reduction of both DNA and RNA at injurious levels of $\mathrm{NaCl}$ might be due to its effects on the inhibition of synthesis and intensification of break down (ABo-Kasssem, 2006). The results obtained in the present work showed that folic acid, ascorbic acid or cobalamin alleviated the inhibitory effects of $\mathrm{NaCl}$ on RNA production but did not evoke the same response in case of DNA. Enhanced ascorbate content was not itself sufficient to stimulate DNA production. Similarly this is the case in folic acid and cobalamin treated seedlings (Table 5). Consequently, one can say that vitamins regulate DNA synthesis at the genome level (Noctor and Foyer, 1998).

Table 5 Effects of folic acid, ascorbic acid or cobalamin on nucleic acid contents of Linum usitatissimum seedlings grown under salt stress conditions. Values are listed are expressed as mg / g dry weight.

Each value is a mean of three replicates $\pm \mathrm{SE}$

\begin{tabular}{|c|c|c|c|}
\hline Treatments & $\begin{array}{c}\boldsymbol{N a C l} \\
(\boldsymbol{m M})\end{array}$ & $\boldsymbol{R N A}$ & $\boldsymbol{D N A}$ \\
\hline & 000 & $5780 \pm 14.0$ & $280.7 \pm 5.5$ \\
$\mathrm{NaCl}$ & 100 & $5410 \pm 12.4$ & $172.7 \pm 9.5^{\mathrm{b}}$ \\
& 200 & $4680 \pm 10.1^{\mathrm{b}}$ & $165.4 \pm 8.4^{\mathrm{c}}$ \\
& 300 & $4320 \pm 10.3^{\mathrm{b}}$ & $132.4 \pm 7.3^{\mathrm{b}}$ \\
\hline & 100 & $6910 \pm 11.6^{\mathrm{c}}$ & $132.1 \pm 7.2^{\mathrm{a}}$ \\
$\mathrm{NaCl}+$ folic acid & 200 & $6510 \pm 14.9^{\mathrm{c}}$ & $107.3 \pm 8.4^{\mathrm{b}}$ \\
& 300 & $5120 \pm 12.8^{\mathrm{b}}$ & $101.4 \pm 7.0^{\mathrm{b}}$ \\
\hline & 100 & $6201 \pm 18.9^{\mathrm{b}}$ & $145.1 \pm 6.4^{\mathrm{a}}$ \\
$\mathbf{N a C l}+$ ascorbic & 200 & $6108 \pm 16.4^{\mathrm{b}}$ & $118.5 \pm 7.8^{\mathrm{b}}$ \\
acid & 300 & $5822 \pm 13.2^{\mathrm{b}}$ & $115.2 \pm 8.2^{\mathrm{b}}$ \\
\hline & 100 & $6690 \pm 14.5^{\mathrm{c}}$ & $130.1 \pm 7.9^{\mathrm{b}}$ \\
$\mathbf{N a C l}+$ cobalamin & 200 & $6652 \pm 18.2^{\mathrm{c}}$ & $113.3 \pm 7.7^{\mathrm{b}}$ \\
& 300 & $5690 \pm 12.2^{\mathrm{b}}$ & $110.1 \pm 7.3^{\mathrm{b}}$ \\
\hline
\end{tabular}

Values with a superscript are significant different from the control. Letter $\mathrm{a}=*$ at $\mathrm{P}>0.05, \mathrm{~b}=* *$ at $\mathrm{P}<0.01, \mathrm{c}=* * *$ at $\mathrm{P}<0.001$, and absence of letter $=$ non significant.

In conclusion, salinized flax seedlings were thus ill equipped to face salt stress. The mechanism of these vitamins on alleviating salt stress hazards of flax seedlings might be mediated by stimulating the de novo synthesis of new set of low molecular weight proteins, reduction in some ions $(\mathrm{Na}$ and $\mathrm{Cl})$ coupled with increases in the accumulation of others $(\mathrm{K}$, $\mathrm{Ca}, \mathrm{P}$ and $\mathrm{Mg}$ ) and consequently the maintenance of high percentage of MSI throughout the experiment.

\section{REFERENCES}

Abo-Kassem $\boldsymbol{E} \boldsymbol{E} \boldsymbol{M}$ (2006): Effects of salinity: Calcium interaction on growth and nucleic acid metabolism in five species of chenopodiaceae. Turk J Bot. 31, 125-134.

Alpaslan M, Gunes A (2001): Interactive effects of boron and salinity on the growth, membrane permeability and mineral composition of tomato and cucumber plants. J Plant Soil . 236, 123-128. 
Alves da Costa PH, Azevedo Neto AD, Alves Bezerra M, Prisco JT, Gomes-Filho E (2005): Antioxidant-enzymatic system of two sorghum genotypes differing in salt tolerance. Braz. J Plant Physiol. 17, 353-361.

Andrew WJ, Youngkoo C, Chen X, Pandalai SG (2000): Vicissitudes of a vitamin. Recent Research developments in Phytochemistry 4, 89-98.

Ashraf M, Harris PJ (2004): Potential biochemical indicators of salinity tolerance in plants. Plant Sci. 166, 3-16.

Azooz MM (2009): Foliar application with riboflavin (vitamin $\mathrm{B}_{2}$ ) enhancing the resistance of Hibiscus sabdariffa L. (Deep Red Sepals Variety) to salinity stress. J Biol Sci. 9, 109-118.

Boscaiu M, Estrelles E, Soriano P, Vicente $O$ (2005): Effects of salt stress on the reproductive biology of the halophyte Plantago crassifolia. Biol Plant. 49, 141-143.

Chapman HD, Pratt PF (1961): Methods for analysis for soil, plant and water. Univ. of California, Division of Agric Sci. 150-157.

Cicek N, Cakirlar $\boldsymbol{H}$ (2002): The effect of salinity on some physiological parameters in two maize cultivars. Bulg. J Plant Physiol. 28, 66-74.

De Abreu IN, Mazzafera P (2005). Effect of water and temperature stress on the content of active constituents of Hypericum brasilienne choisy. Plant Physiol Biochem. 43, 241-248.

Dunn MJ (1993). Gel electrophoresis: Proteins. Bios Scientific Publishers, Ltd Oxford, UK 176 .

El-Bassiouny HMS, Gobarah ME, Ramadan AA (2005): Effect of antioxidants on growth, yield and Favism Causative Agents in seeds of Vicia faba L. plants grown under reclaimed sandy soil. J Agron. 4, 281-287.

El- Bassuiony FM, Hassanein RA, Baraka DM, Khalil RR (2008): Physiological effects of nicotinamide and ascorbic acid on Zea mays plant grown under salinity stress. II- Changes in nitrogen constituents, protein profile, protease enzyme and certain inorganic cations. Aust J Basic Appl Sci. 2, 350-359.

El-Tohamy WA, El-Gready NHM (2007): Physiological responses, growth, yield and quality of snap beans in response to foliar application of yeast, vitamin $\mathrm{E}$ and zinc under sandy soil conditions. Aust. J. Basic Appl Sci 1. 294-299.

Eraslan F, Inal A, Gunes A, Alpaslan M (2007): Impact of exogenous salicylic acid on the growth, antioxidant activity and physiology of carrot plants subjected to combined salinity and boron toxicity. Sci Hortic. 113, 120-128.

Ericson MC, Alfinito SH (1984). Proteins produced during salt stress in tobacco cell culture. Plant Physiol. 74, 506-509.

Esaka M, Hayakawa H, Hashimoto M, Matsubara $N$ (1992): Specific and abundant secretion of a novel hydroxylation proline-rich glycoprotein from salt-adapted winged bean cells. Plant Physiol. 100, 1339-1345.

Faheed FA, Hassanein A, Azooz MM (2004): Overcoming salt-induced germination inhibition by gradual increase of $\mathrm{NaCl}$ in Sorghum bicolor L. Proceedings, Egyptian Botanical Society Conference, Stress in Plants, Ain Shams University, Cairo. 124-140. 
Ghoulam, C. and Fares, K. (2001): Effect of salinity on seed germination and early seedling growth of sugar beet (Beta vulgaris L). Seed Sci. Techn. 29: 357-364.

Hamad AAM, Hamada AM (2005): Grain soaking presowing in ascorbic acid or thiamin in versus the adverse effects of combined salinity and drought on wheat seedlings. in Proceedings of the 12th International Congress of Photosynthesis (Melbourne, Australia,Brisbane, August 18-23, 2001), CSIRO Publishing, S15005 .

Hamed BA (2004): Effect of urea and some urea derivatives either alone or in mixture on Rocket (Eruca sativa, Mill) grown under saline condition. Egyptian Botanical Society Conference, Stress in Plant. Ain Shams University Cairo Egypt, March $3^{\text {rd }}, 17-30$.

Hasegawa PM, Bressan RA (2000): Plant cellular and molecular responses to higher salinity. Annu Review Plant Mol Biol. 51, 463-499.

Hong-Bo S, Zong-Suo L, Ming-An S (2005): LEA proteins in higher plants: structure, functions, gene expression and regulation. Colloids and Surfaces. 45, 131-135.

Howell, S.H. (1998): Molecular genetics and plant development. Cambridge University Press, Cambridge, UK, 365.

Humphries EC (1956): Mineral component and ash analysis. In: Modern Methods of Plant Analysis (Peach, K. and Tracey, M. V., Ed) I. 148, Springer-Verlag. Berlin.

Hurkman WJ, Tanaka CK (1987): The effect of salt on the pattern of protein synthesis in barley roots. Plant Physiol. 83, 517-524.

Hurkman WJ, Farnari CS, Tanaka CK (1989): A comparison of the effect of salt on polypeptides and translatable mRNAs on root of a salt tolerant and a salt sensitive cultivar of barley. Plant Physiol. 90, 1444-1456.

Inal $\boldsymbol{A}$ (2002). Growth, proline accumulation and ionic relations of tomato (Lycopersicon esculentum L.) as influenced by $\mathrm{NaCl}$ and $\mathrm{Na}_{2} \mathrm{SO}_{4}$ salinity. Turk. J Bot. 26, 285-290.

Inal A, Gunes A, Pilbeam DJ, Kadioglu YK, Eraslan F (2009): Concentrations of essential and non essential elements in shoots and storage roots of carrot grown in $\mathrm{NaCl}$ and $\mathrm{Na}_{2} \mathrm{SO}_{4}$ salinity. X-Ray Spectrum. 38, 45-51.

Izzo R, Navari-Izzo F, Quarticci MF (1991): Growth and mineral absorption in maize seedlings as affected by increasing $\mathrm{NaCl}$ concentrations. J Plant Nutr. 14, 687701.

Jackson WA, Thomas $\boldsymbol{G W}$ (1960): Effect of $\mathrm{KCl}$ and dolometric limestone on growth and ion uptake of sweet potato. Soil Sci. 89, 347-352.

Jeschke WD, Aslam Z, Greenway H (1986): Effects of $\mathrm{NaCl}$ on ion relations and carbohydrate status of roots and on osmotic regulation of root and shoots of Atriplex amnicola. Plant Cell and Environ. 9, 559-569.

Kabir ME, Karim MA, Azad MAK (2004): Effect of potassium on salinity tolerance of mung bean (Vigna radiate L. Wilezek). J Biol Sci. 4, 103-110.

Khattab $\boldsymbol{H}$ (2001): The interaction effects of salinity and certain bioregulators on the protein metabolism of two different rice cultivars. Egyp. J. Biotechnol. 9, 39-54. 
Lacerda CF, Cambraia J, Oliva MA, Ruiz HA, Prisco JT (2003). Solute accumulation and distribution during shoot and leaf development in two sorghum genotypes under salt stress. Environ. Exp. Bot. 49, 107-120.

Laemmli UK (1970): Cleavage of structural head of bacteriophage. Nature. 722, 680-685.

Lechno S, Zamski EM, Tel-Or E (1996): Salt stress-induced responses in cucumber plants. J Plant Physiol. 150, 206-211.

Li J, Wang Z (1991): Effects of active oxygen scavengers on the activities of protective enzymes in waterlogged corn plants. J Agric Sci. 7, 23-28.

Lutts S, Kinet JM, Bouharmon J (1996): Effects of salt stress on growth, mineral nutrition and proline accumulation in relation to osmotic adjustment in rice (Oryza sativa L.) cultivars differing in salinity resistance. j Plant Growth Regul. 19, 207-218.

López M, Tejera NA, Liuch C (2008). Differential strategies of the model legumes Lotus japonicus and Medicago truncatula in the adaptation to salt stress: Photosynthetic and nutritional responses. Am J Plant Physiol. 3, 121-130.

Mozafar A, Oertli JJ (1992). Uptake of microbially produced vitamin $\left(\mathrm{B}_{12}\right)$ by soybean roots. Plant and Soil J.,139, 23-30.

Napier RM, Venis MA (1990): Monoclonal antibodies detect an auxin-induced conformational change in the maize auxin-binding protein. Planta 182, 313318.

Natarajan K, Kishore L, Babu CR (1996: Proteins associatedwith $\mathrm{NaCl}$

stress in Rhizobium have adaptive role in osmotolerance. Microbios. 85, 89-104.

Noctor G, Foyer $\boldsymbol{C H}$ (1998): Ascorbate and glutathione: Keeping active oxygen under control. Plant Mol Biol 49, 249-279.

Nuran, Ç. and Hüsnü, Ç. (2002): The effect of salinity on some physiological parameters in two maize cultivars. Bulg. J. Plant Physiol. 28: 66-74.

Ogur J, Rosen G (1950): The nucleic acids of plant tissue I. The extraction and estimation of deoxypentose nucleic acid and pentose nucleic acid. Arch. Biochem. 26, 262.

Pardo JM, Reddy MP, Yang S, Maggio A, Huh GH, Matsumoto T, Coca MA, PainoD'urzo M, Koiwa H, Yun D-J, Watad AA, Bressan RA, Hasegawa PM (1998): Stress signaling through $\mathrm{Ca}^{2+} /$ calmodulin-dependent protein phosphatase calcineurin mediates salt adaptation in plants. Proc Natl Acad Sci USA 95, 9681-9686.

Pastori GM, Foyer CH (2002): Common components, networks, and pathways of crosstolerance to stress. The central role of redox and abscisic acid-mediated controls. Plant Physiol J 129, 7460-7468.

Radi, A.F., Heikal, M.M., Abdel-Rahman, A.M. and El-Deep, B.A.A. (1988): Interactive effects of salinity and phytohormones on growth and plant water relationship parameters in maize and safflower plants. Revue Roumaine De Biologie. Serie De Biologie. 33: 27-37.

Ramagopal, S. and Carr, J.B. (1991): Sugar cane proteins and mRNAs regulated by salt in suspension cells. Plant Cell Environ. 14: 47-56. 
Ranganna $S$ (1977). Manual Analysis of Fruits and Vegetables Products. Mc Grow-Hill Publishing Company, New Delhi Pp. 363.

Rejil M, Vadel AM, Guetet A, Neffatti M (2007:. Effect of $\mathrm{NaCl}$ on growth and the ionic balance $\mathrm{K}^{+} / \mathrm{Na}^{+}$of two populations of Lotus creticus (L.) (Papilionaceae). South Afric J. Bot 73, 623-631.

Reviron MP, Vartanian N, Stallantin M, Huet JC, Pernollet JC, de Vienne D (1992): Characterization of a novel protein induced by progressive or rapid drought and salinity in Brassica napus leaves. Plant Physiol. 100, 1486-1493.

Robinson NL, Tanaka CK, Hurkman WJ (1990): Time dependent changes in polypeptide translatable mRNA levels caused by $\mathrm{NaCl}$ in barley roots. Plant Physiol. 78, $128-134$

Roussos PA, Gasparatos D, Tsantili E, Pontikis CA (2007): Mineral nutrition of Jojoba explants in vitro under sodium chloride salinity. Sci. Hortic. 117, 59-66.

Sairam RK, Deshmukh PS, Shukla DS (1997): Tolerance to drought and temperature stress in relation to increased antioxidant enzyme activity in wheat. J Agron Crop Sci. $178,171-177$.

Salter J, Morris K, Bailey PCE, Boon PI (2007): Interactive effects of salinity and water depth on the growth of Melaleuca ericifolia (Swamp paperbark) seedlings. Aquatic Bot. 86, 213-222.

Serrano R, Rodriguez-Naarro A (2001): Ion homeostasis during salt stress in plants. Curr Opin Cell Biol. 13, 399-404.

Schneider WC (1945): Phosphorus compounds in animal tissues. I. Extraction and estimation of deoxypentose nucleic acid and of pentose nucleic acid. J Biol Chem. 161, 293.

Shalata A, Neumann MP (2001): Exogenous ascorbic acid (vitamin c) increases resistance to salt stress and reduces lipid peroxidation. $J$ Exp Bot. 52, 2207-2211.

Sharma, S.K. (1990): Studies on growth, water relations and distributing of $\mathrm{Na}^{+}, \mathrm{K}^{+}$and other ions in wheat under shoot term exposes to salinity, Ind. J. Plant Physiol. 38: $233-235$.

Singh NK, Bracker CA, Hasegawa PM, Handa AK, Buckel, S, Hermodson MA, Pfankoch E, Regnier FE, Bressan RA (1987): Characterization of osmotin, a thoumatinlike protein associated with osmotic adaptation in plant cells. Plant Physiol 85, 529-536.

Sivritepe N, Sivritepe HO, Eris A (2003): The effect of $\mathrm{NaCl}$ priming on salt tolerance in melon seedlings grown under saline conditions. Sci. Hortic. 97, 229-237.

Smith AG, Croft MT, Moulin M, Webb ME (2007): Plants need their vitamins too. Physiol. Metab. 10, 266-275.

Studeir $\boldsymbol{F W}$ (1973): Analysis of bacteriophage $\mathrm{T}_{4}$, early RNAs and proteins on slab gels. J Mol Biol. 79, 237-248.

Sudhakar C, Lakshmi A, Giridarakumar $S$ (2001): Changes in the antioxidant enzyme efficiency in two high yielding genotypes of mulberry (Morus alba L.) under NaCl salinity. Plant Sci. 161, 613-619. 
Ungar, I.A. (1996): Effect of salinity on seed germination, growth, and ion accumulation of Atriplex payola (chenopodiaceae). Am. J. Bot. 83: 604-607.

Winicov I, Button JD (1991): Accumulation of photosynthesis gene transcripts in response to sodium chloride by salt-tolerant alfalfa cells. Planta. 183, 478-483.

Word CM, Johnston FB (1962): Chemical Method of Plant Analysis. Publication, 1964, Research Branch, Canada Dept. of Agric.

Yildirim E, Taylor A, Spittler T D (2006): Ameliorative effects of biological treatments on growth of squash plants under salt stress. Sci. Hortic. 111, 1-6.

Zhao J, Herrmann K M (1992): Cloning and sequencing a second cDNA encoding 3deoxy- D-arabino- heptulosonate-7- phosphate synthase from Solanum tuberosum L. Plant Physiol. 100, 1075-1076.

\title{
تأثير بعض الفيتامينات على الاتزان الايونى والنمط البروتينى لبادرات نبات الكتان تحت ظروف الاجهاد الملحى البروتئ
}

\author{
منال محمد إمام ، نسمة ماهر هلال \\ قسم النبات - كلية العلوم - جامعى عين شمس
}

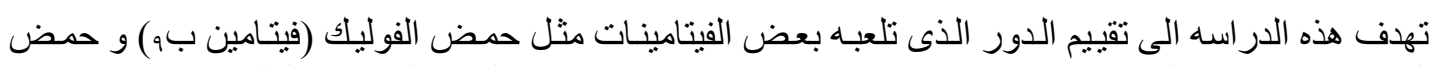

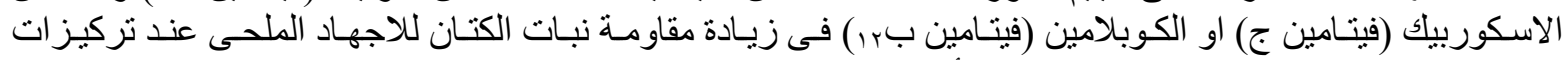

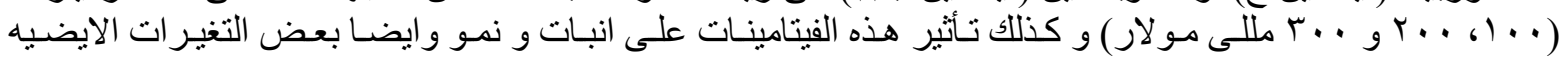
المصاحبه لذلك.

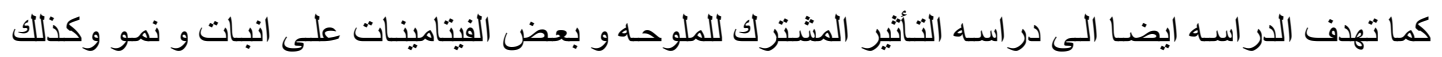

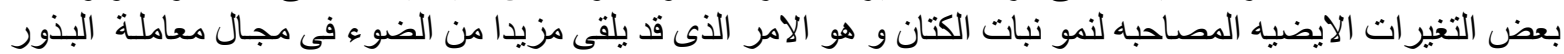

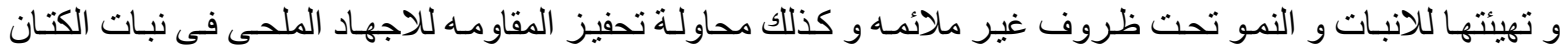
باستخدام الفيتامينات السابق ـ ذكر ها.

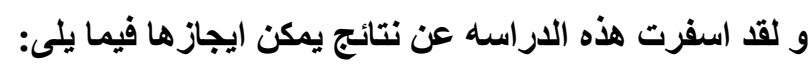

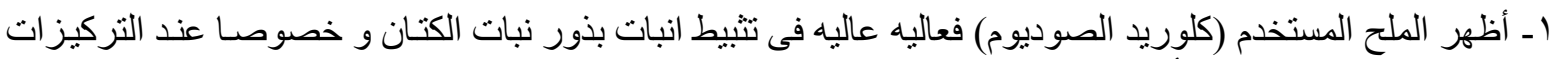

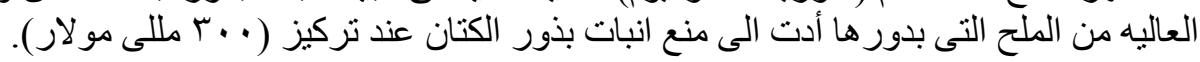
rـ اخنز ال الى حد كبير فى نمو البادر ات خاصه عند المستويات العاليه من الملح.

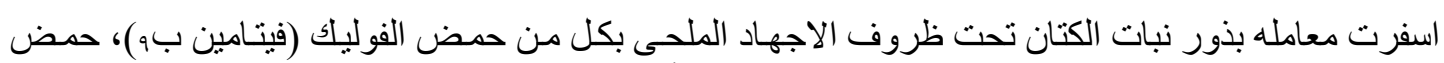

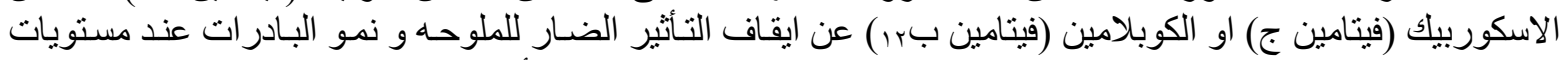

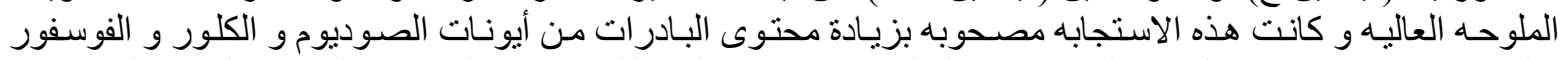

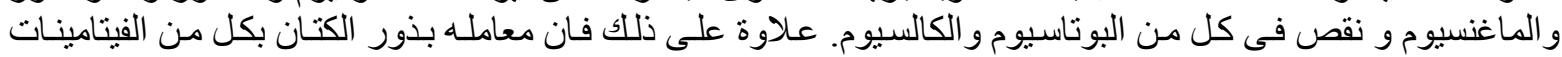

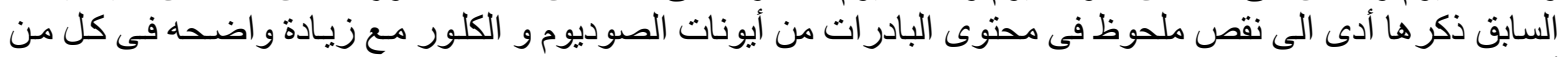
أيونات البوتاسيوم و الكالسيو و الفي ملفو الفسفور و الماغنسيوم.

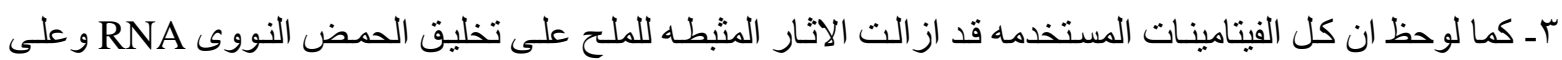

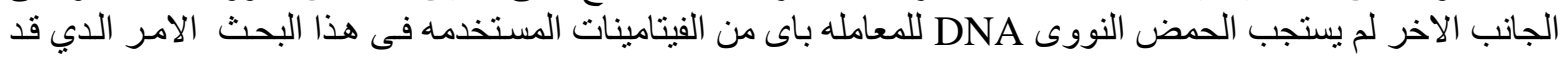
يلعب دورا في از اله الاثار الضاره للاجهاد الملحى وكان هذا ممثلا بزيادة واضحه فى (MSI).

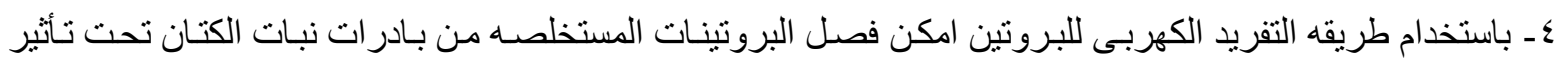

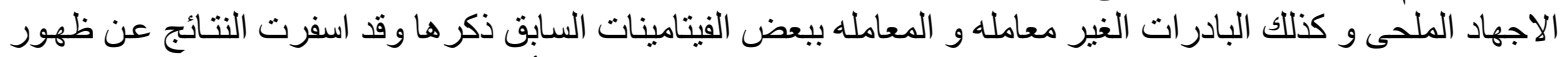

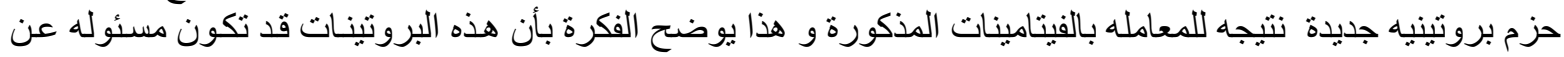

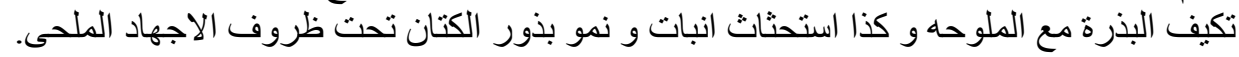

